Исследование выполнено в рамках гранта на проведение научно-исследовательских работ по приоритетным направлениям научной деятельности вузов-партнеров по сетевому взаимодействию (Пермский государственный гуманитарно-педаго- гический университет и Мордовский государственный педагогический институт им. М.Е. Евсевьева) по теме: "Мониторинг качества окружающей среды с помощью растений-биоиндикаторов».

\title{
A COMPARATIVE ENVIRONMENTAL ASSESSMENT USING BIOINDICATOR PLANTS IN CONDITIONS OF ANTHROPOGENIC IMPACT OF SARANSK AND INSAR
}

(C) 2020

Labutina Marina Viktorovna, candidate of biological sciences, associate professor of Biology, Geography and Methods of Teaching Department

Maskaeva Tatiana Aleksandrovna, candidate of biological sciences, associate professor of Biology, Geography and Methods of Teaching Department

Chegodaeva Nina Dmitrievna, candidate of agricultural sciences, associate professor of Biology, Geography and Methods of Teaching Department

Kurynova Evgeniya Aleksandrovna, master student of Biology, Geography and Methods of Teaching Department Mordovian State Pedagogical Institute named after M.E. Evseviev (Saransk, Russian Federation)

Abstract. The paper studies the reaction of pendent white birch (Betula verrucosa) as the main urban culture used in urban greening at different levels of anthropogenic impact. Annual studies indicate that there is no sustainable trend to reduce man-made emissions in the region. Greening of large industrial centers is of great environmental importance. According to morphometric and some reproductive parameters, the birch has an adaptive response to environmental conditions. The studies have shown that habitat conditions directly affect the morphometric and reproductive characteristics of plants. To a greater extent, in conditions of anthropogenic impact increase, the reaction of biomorphological parameters of the pendent white birch is manifested. When using the method of fluctuating asymmetry, its integral indicators showed the reaction of plants to the increase in anthropogenic impact in the city. The germination and germination energy of birch seeds collected from different study sites are indicative in this respect. The variable coefficient on the size of fruits and seedlings revealed, as a rule, a very high variability (20-40\%), which explains the high plasticity of plants to living conditions even at the early stages of their development.

Keywords: anthropogenic pollution; environment; gardening; ecological monitoring; plants-bioindicators; pendent white birch (Betula verrucosa); fluctuating asymmetry; integral index; anatomical and morphological adaptations; generative organs; seed germination; germination energy; growth indicators.

$* * *$ КАК ИНДИКАТОРА ЭКОЛОГИЧЕСКОГО СОСТОЯНИЯ ВОДНОЙ СРЕДЫ НИЗОВИЙ Р. КАМЫ (C) 2020

\author{
Любин Павел Анатольевич, кандидат биологических наук, \\ старший научный сотрудник лаборатории гидробиологии \\ Зиганшин Ирек Ильгизарович, кандидат географических наук, доцент, \\ старший научный сотрудник лаборатории биогеохимии \\ Институт проблем экологии и недропользования Академии наук Республики Татарстан \\ (г. Казань, Российская Федерация)
}

\footnotetext{
Аннотаџия. Проведено исследование зоопланктона в нижнем течении реки Камы, крупнейшего притока Волги, имеющего важное экономическое значение для европейской части России. Полученные результаты позволили установить летний состав фауны зоопланктона исследуемого водоема, определить количественные характеристики сообществ. Был выявлен 61 таксон, относящийся к 3 типам: Rotifera, Arthropoda (группы Cladocera, Copepoda) и Mollusca (Bivalvia). В среднем по району исследования видовая плотность составляет

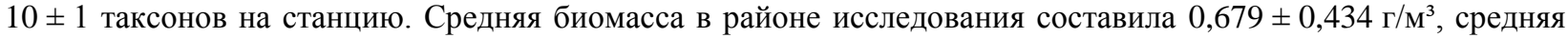

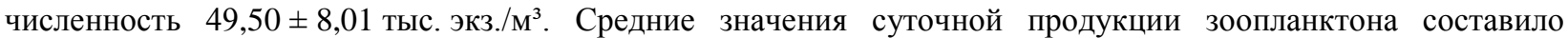
$0,043 \pm 0,020$ г/м³. Проведенный биоценотический анализ позволил выделить в районе исследования пять типов сообществ с доминированием массовых видов коловраток, ветвистоусых и веслоногих рачков. Проведенный двухфакторный анализ показал, что на структуру сообществ сильнее влияют локальные особенности биотопов, чем общие условия на участках исследования. Индекс благополучия указывает, что сообщества зоопланктеров нижнего течения реки Камы находятся в состоянии, близкому к стрессу. По экологической оценке, воды соответствуют умеренно загрязненному классу вод ( $\beta$-мезосапробная зона).

Ключевые слова: экологическое состояние; пространственный анализ; зоопланктон; река Кама; кластерный анализ; оценка уровня самоочищения; Нижнекамское водохранилище; индекс Шеннона; вторичная продукция; биомасса; численность; двухфакторный ANOSIM анализ; индекс сапробности; индекс благополучия.
} 


\section{Введение}

Река Кама - один из крупнейших притоков реки Волги, имеющий важное хозяйственное значение для Европейской части России. Длина водотока, по данным Государственного водного реестра (Гос), составляет 1805 км, водосборная площадь 507000 км² $^{2}$ В реку Каму впадают более 100 рек и 50 озер. На реке создано три водохранилища и ГЭС. В нижнем течении реки, где проводились наши исследования, на реке Каме имеется два зарегулированных участка. Участок 1 (рис. 1) в устьевой части р. Камы от места впадения реки в Волгу до острова Сокольский (село Соколка) включается в Куйбышевское водохранилище. Выше по течению до плотины Нижнекамской ГЭС, расположен участок 2 (рис. 1) реки с довольно сильным течением. На данном отрезке реки в Каму впадает река Вятка. Выше плотины находится Нижнекамское водохранилище (участок 3 , рис. 1). В пределах района исследования на берегах Камы расположены города Чистополь, Нижнекамск, Набережные Челны, Мензелинск и другие населенные пункты. На реке осуществляется судоходство и активно добывается песчано-гравийные смеси. Река Кама имеет высокое рыбохозяйственное значение. Все эти обстоятельства свидетельствуют о важном значении реки Камы и необходимости проведения постоянного мониторинга за экологическим состоянием вод.

Зоопланктон является важной структурной и функциональной частью экосистем водных объектов, участвует в самоочищении водоемов и служит индикатором их состояния, чутко реагируя на изменение как природных, так и антропогенных факторов [1]. Зоопланктон реки Камы к настоящему времени наиболее изучен в верховье в Камском и Воткинском водохранилищах [2-5]. Существенно менее зоопланктон изучен в нижнем течении - Камского плеса Куйбышевского водохранилища [6; 7]. Зоопланктон Нижнекамского водохранилища фактически не изучен, имеются лишь сведения о его количественных характеристиках летом 1975 г. до зарегулирования этого участка реки [8]. Последние исследования зоопланктона реки Камы проводились в 2016 г. силами Института биологии внутренних вод им. И.Д. Папанина РАН (ИБВВ РАН) [9]. Авторы подводят итог пятилетних исследований водохранилищ волжскокамского каскада со сравнительным анализом видового и количественного распределения зоопланктона. В работе проведен подробный анализ зоогеографического распределения видов зоопланктона, выявлены особенности их распределения, для многих видов определены время их вселения в те или иные водоемы. Однако в работе отсутствует оценка санитарного состояния вод, что очень важно для определения современного состояния водоема и контроля его последующего изменения.

Институт проблем экологии и недропользования (ИНЭП АН РТ, г. Казань) также провел комплексные гидробиологические исследования на реке Каме в 2016 г. с целью установить санитарное состояние водоема. Одним из компонентов исследования было изучение сообществ зоопланктона. В настоящем сообщении нами приводятся результаты данных исследований, целью которых было определить видовой состав и количественные характеристики зоопланктона в нижнем течении реки Камы, определить санитарное состояние вод, и провести сравнительный анализ полученных нами результатов с данными исследований ИБВВ РАН и более ранними исследованиями.

\section{Материал и методы исследования}

Гидробиологическое обследование нижнего течения реки Камы проведено в период с 28 июля по 9 августа 2016 года. Местоположение гидробиологических станций определялись в соответствии с экспедиционным заданием. Пробы воды (по 50 литров на каждой станции) отбирались в прибрежной полосе ведром с поверхностного слоя и фильтровались через сеть Апштейна с газом № 74 (с номинальным размером ячейки 0,093 мм) в соответствии со стандартными гидробиологическими методами [10; 11]. Пробы фиксировались 4\% раствором формалина. Глубина в месте отбора проб не превышала 1 м. Для таксономической идентификации организмов зоопланктона использовались общепринятые определители [12-14]. Расчет биомассы зоопланктона проводился по формулам зависимости массы организмов от длины тела $[15 ; 10]$.

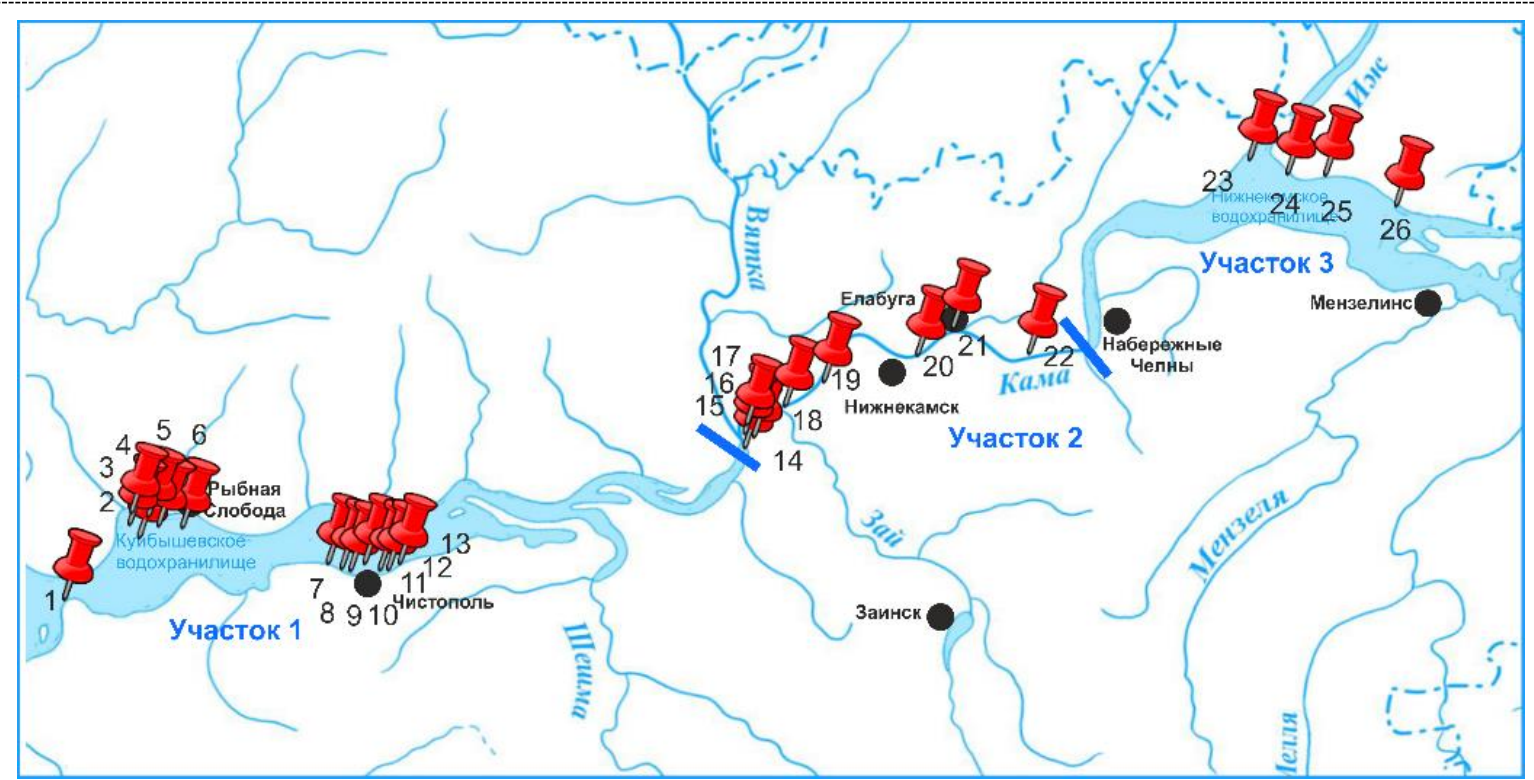

Рисунок 1 - Карта района работ на реке Кама в июле-августе 2016 г. 
Любин П.А., Зиганшин И.И.

Состав и структура зоопланктона как индикатора экологического состояния водной среды..

Общая биология

Для каждого вида определялась встречаемость - $\mathrm{Pi}$ :

$$
P i=m i / N s,
$$

где $m i$ - число станций, в которых был найден вид $i$, $N s$ - общее количество станций.

Для количественной оценки значимости видов при классификационных построениях (оценки сходства между станциями) использована величина экспресс оценки продукции популяции таксона по среднему весу его особей, предложенная И.Е. Манушиным [16]:

$$
P=B \cdot 0.0019 \cdot(B / N)^{-0.39},
$$

где $P$ - суточная продукция вида/таксона, г/M ${ }^{3} /$ сутки;

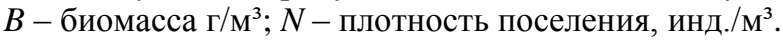

Из-за большой неопределенности продукционных параметров и отсутствия данных о рационе хищников общая продукция зоопланктонного сообщества $P_{1}$ рассчитывалась как суммарная продукция крупных (весом $10^{-5}$ г и более) зоопланктеров, в соответствии с методической рекомендацией [10]. Суммарная продукция более мелких (весом менее $10^{-5}$ г) 30опланктеров $P_{2}$ рассчитывалась отдельно.

Сообщества выделялись методом кластерного анализа с использованием для расчета меры сходства станций количественного индекса Чекановского [17], индекс сходства выражался в \%. Кластеризация проводилась метод средневзвешенного среднего [18]. Проверка статистической значимости выделенных кластеров выполнялась имитационным анализом сходства ANOSIM в программе Primer 5 (PRIMER-E Ltd) [19-21]. Выделенные сообщества обозначались в соответствии с видами, доминирующими по величине суточной продукции, без учета личиночных стадий копепод. Выделение доминирующих видов проводилось в соответствии со шкалой Е.Л. Любарского [22].

В качестве обобщенного показателя видового разнообразия использована широко применяемая для этих целей информационная мера Шеннона ( $\left.H^{\prime}\right)$ [23], рассчитываемая по формуле:

$$
\bar{H}=\sum\left(\frac{n_{i}}{N} \log _{2}\left(\frac{n_{i}}{N}\right)\right)^{\prime}
$$

где $n_{i}-$ количество особей і-го вида/таксона в пробе, $N$ - общее количество особей в пробе.

Для оценки общего экологического состояния (благополучия) зоопланктонных сообществ использован индекс преобладающей жизненной стратегии или экологического благополучия $\left(D_{E}\right)$, основанный на сопоставлении информационного разнообразия видов по численности и биомассе и вычисляемый по формуле [24]:

$$
D_{E}=\left[H^{\prime}(B)-H^{\prime}(N)\right] / \log _{2}(S),
$$

где $H^{\prime}(B)$ и $H^{\prime}(N)$ - индекс Шеннона, рассчитанный по биомассе и по численности особей; $S$ - количество видов в выборке.

Оценка качества воды проводилась путем расчета индекса сапробности $(S)$ по Пантле-Букку [25] в модификации Сладечека [26; 27].

Оценка уровня самоочищения $(K)$ проводилась по формуле [28; 29]:

$$
\mathrm{K}=\frac{\mathrm{P} o+0.5 \mathrm{P} \beta}{\mathrm{P} \alpha \rho+0.5 \mathrm{P} \beta},
$$

где Рo - процент содержания в пробе воды организмов, приуроченных к чистым средам обитания (оли68 госапробы), $\mathrm{P} \beta$ - процент $\beta$-мезосапробов, Р $\alpha p-$ процент суммы представителей зоопланктонного населения, выдерживающих высокую степень загрязнения ( $\alpha$-мезосапробы и полисапробы).

Всего было отобрано и изучено 26 проб зоопланктона, просмотрено 1516 экземпляров зоопланктеров.

\section{Результаты исследований и их обсуждение}

По данным обработки проб зоопланктона низовья р. Камы, собранных в июле-августе 2016 г., был выявлен 61 таксон (табл. 1), определенный до видового и надвидового ранга, а также личиночные стадии беспозвоночных, относящихся к 3 типам: Rotifera, Arthropoda (группы Cladocera, Copepoda) и Mollusca (Bivalvia) (табл. 1). Около 63\% от всех обнаруженных видов приходилось на долю коловраток. Кладоцеры были представлены 11 видами, а копеподы были представлены двумя видами из отряда Colanoida и двумя видами из отряда Cyclopoida. Кроме этого, в пробах имелись науплиальные и копеподитные личиночные стадии веслоногих рачков. В пробах планктона нами также были встречены великонхи личинки двустворчатых моллюсков.

Количество таксонов на станциях колебалось от 3 до 21. Максимальное количество было встречено на акватории вблизи г. Чистополя - 21 таксон (ст. 13). Минимальное количество отмечено ниже г. Елабуга (ст. 21) - 2 таксона на станцию. По числу таксонов на станциях, как правило, преобладали коловратки, их доля доходила до $73 \%$, в среднем составила $48 \%$. На втором месте по количеству таксонов на станциях стоят веслоногие рачки, в среднем их доля составила $28,6 \%$. Третье место принадлежит ветвистоусым рачкам, в среднем на станциях их доля составляла около 20\%. Личинки двустворчатых моллюсков встретились на 12 станциях. Наибольшее количество таксонов было встречено в Камском отроге Куйбышевского водохранилища - 44. В среднем на данном участке встречается по $12 \pm 1$ таксонов на станции. На участке 2, с реофильными условиями, было обнаружено 34 таксона, в среднем на станцию приходилось по $9 \pm 1$ таксонов. На участке 3 Нижнекамского водохранилища было зарегистрировано 17 видов, в среднем на станции встречалось по $8 \pm 2$ видов. В среднем по району исследования видовая плотность составляет $10 \pm 1$ таксонов на станцию.

Численность зоопланктона на исследованных станциях изменялась в широком диапазоне значений от 0,44 тыс. до 134,46 тыс. экз./ $\mathrm{M}^{3}$, составляя в среднем 49,50 $\pm 8,01$ тыс. экз./ $\mathrm{M}^{3}$. Минимальные значения численности были отмечены в районе г. Елабуга (ст. 21), максимальные в районе поселка Рыбная Слобода (ст. 3). В среднем обилие зоопланктеров было выше в Камском отроге Куйбышевского водохранилища (участок 1) - 64,6 $\pm 12,6$ тыс. экз./ $\mathrm{M}^{3}$. На данном участке по численности на станциях преобладали копеподы - 48\%, на долю коловраток приходилось около $32 \%$ всей численности планктеров, на долю кладоцер приходилось около 19\% всей численности, менее 1\% приходилось на долю моллюсков. На участке 2, где имеется течение, численность зоопланктона была ниже $-43,3 \pm 11,7$ тыс. экз./м³. На участке с реофильными условиями доминировали коловратки, их доля составляла $56 \%$, на втором месте были копеподы $27 \%$, численность кладоцер не достигала $16 \%$ от общей численности, $2 \%$ приходилось на долю личинок двустворчатых моллюсков. На станциях Нижнекамского водохранилища средняя 
Любин П.А., Зиганшин И.И.

Общая биология Состав и структура зоопланктона как индикатора экологического состояния водной среды...

плотность зоопланктона составила 14,1 $\pm 2,5$ тыс. экз./Mㄹ. На станциях 3-го участка по численности также доминировали копеподы 49\%, а на втором месте по численности были личинки двустворчатых моллюсков - $19 \%$, доля коловраток и кладоцер составила соответственно $18 \%$ и $14 \%$. В целом числен- ность зоопланктеров в районе исследования распределена почти в равных долях между копеподами, на их долю приходится $40 \%$ и коловратками - $38 \%$. На долю кладоцер приходится в среднем $18 \%$ численности всех зоопланктеров, а численность личинок двустворчатых моллюсков в планктоне составляет 4\%.

Таблица 1 - Видовой состав и частота встречаемости таксонов на станциях в нижнем течении реки Камы по данным июля-августа 2016 г.

\begin{tabular}{|c|c|c|c|c|}
\hline Таксоны & Участок-1 & Участок-2 & Участок-3 & В целом \\
\hline \multicolumn{5}{|l|}{ Rotifera } \\
\hline Asplanchna priodonta Gosse, 1850 & 0,85 & 0 & 0,25 & 0,46 \\
\hline Asplanchna sieboldi Leydig, 1854 & 0 & 0,44 & 0 & 0,15 \\
\hline Brachionus angularis Gosse, 1851 & 0,54 & 0,67 & 0,5 & 0,58 \\
\hline Brachionus budapestinensis Daday, 1885 & 0,31 & 0 & 0 & 0,15 \\
\hline Brachionus calyciflorus Pallas, 1776 & 0,77 & 0,67 & 0,25 & 0,65 \\
\hline Brachionus diversicornis (Daday, 1883) & 0,62 & 0,33 & 0,25 & 0,46 \\
\hline Brachionus quadridentatus Herman, 1783 & 0,15 & 0,11 & 0 & 0,12 \\
\hline Cephalodella ventripes (Dixon-Nuttall, 1901) & 0 & 0,22 & 0 & 0,08 \\
\hline Conochilus unicornis Rousselet, 1892 & 0,38 & 0 & 0 & 0,19 \\
\hline Euchlanis dilatata Ehrenberg, 1832 & 0 & 0,11 & 0 & 0,04 \\
\hline Euchlanis lyra Hudson, 1886 & 0,08 & 0 & 0,5 & 0,12 \\
\hline Filinia longiseta (Ehrenberg, 1834) & 0,15 & 0 & 0 & 0,08 \\
\hline Filinia terminalis (Plate, 1886 ) & 0,08 & 0 & 0 & 0,04 \\
\hline Kellicottia longispina (Kellicott, 1879) & 0 & 0,11 & 0 & 0,04 \\
\hline Keratella cochlearis (Gosse, 1851) & 0,08 & 0 & 0 & 0,04 \\
\hline Keratella irregularis (Lauterborn, 1898) & 0,08 & 0 & 0 & 0,04 \\
\hline Keratella quadrata (Müller, 1786) & 0,31 & 0,22 & 0 & 0,23 \\
\hline Keratella tropica (Apstein, 1907) & 0,08 & 0 & 0 & 0,04 \\
\hline Lecane luna (Müller, 1776) & 0,08 & 0 & 0 & 0,04 \\
\hline Philodina acuticornis Murray, 1902 & 0 & 0,11 & 0 & 0,04 \\
\hline Polyarthra dolichoptera Idelson, 1925 & 0,08 & 0 & 0 & 0,04 \\
\hline Polyarthra euryptera Wierzejski, 1891 & 0,15 & 0 & 0 & 0,08 \\
\hline Polyarthra longiremis Carlin, 1943 & 0,15 & 0 & 0 & 0,08 \\
\hline Polyarthra luminosa Kutikova, 1962 & 0,15 & 0 & 0,25 & 0,12 \\
\hline Polyarthra major Burckhardt, 1900 & 0 & 0,22 & 0 & 0,08 \\
\hline Polyarthra vulgaris Carlin, 1943 & 0,23 & 0,11 & 0 & 0,15 \\
\hline Rotaria neptunia (Ehrenberg, 1830) & 0 & 0,11 & 0 & 0,04 \\
\hline Synchaeta longipes Gosse, 1887 & 0,08 & 0 & 0 & 0,04 \\
\hline Synchaeta pectinata Ehrenberg, 1832 & 0 & 0,11 & 0 & 0,04 \\
\hline Trichocerca capucina (Wierzejski \& Zacharias, 1893) & 0,31 & 0 & 0 & 0,15 \\
\hline Trichocerca cylindrica (Imhof, 1891) & 0,08 & 0,11 & 0 & 0,08 \\
\hline Trichocerca elongata (Gosse, 1886) & 0,15 & 0 & 0 & 0,08 \\
\hline Trichocerca inermis (Linder, 1904) & 0,08 & 0 & 0 & 0,04 \\
\hline Trichocerca longiseta (Schrank, 1802) & 0 & 0,11 & 0 & 0,04 \\
\hline Trichocerca pusilla (Jennings, 1903) & 0,08 & 0,22 & 0,25 & 0,15 \\
\hline Trichocerca rattus (Müller, 1776) & 0 & 0,11 & 0 & 0,04 \\
\hline Trichocerca similis (Wierzejski, 1893) & 0,31 & 0,11 & 0 & 0,19 \\
\hline Trichocerca stylata (Gosse, 1851) & 0 & 0,11 & 0 & 0,04 \\
\hline Trichotria tetractis (Ehrenberg, 1830) & 0 & 0,11 & 0 & 0,04 \\
\hline Rotifera g. sp. & 0,23 & 0,33 & 0,25 & 0,27 \\
\hline Итог: Rotifera & $6,64(28)$ & $4,75(22)$ & $2,5(8)$ & $5,38(40)$ \\
\hline \multicolumn{5}{|l|}{ Cladocera } \\
\hline Alona affinis (Leydig, 1860) & 0 & 0,11 & 0 & 0,04 \\
\hline Bosmina longirostris (Müller, 1785) & 1 & 0,33 & 0,25 & 0,65 \\
\hline Ceriodaphnia reticulata (Jurine, 1820) & 0,08 & 0,11 & 0 & 0,08 \\
\hline Chydorus sphaericus (Müller, 1785) & 0,54 & 0 & 0 & 0,27 \\
\hline Cornigerius maeoticus (Pengo, 1879) & 0,23 & 0 & 0 & 0,12 \\
\hline Daphnia cucullata Sars, 1862 & 0 & 0,22 & 0 & 0,08 \\
\hline Daphnia longispina O.F. Muller, 1785 & 0,15 & 0,33 & 0,5 & 0,27 \\
\hline Diaphanosoma brachyurum (Lievin, 1848) & 0 & 0 & 0,75 & 0,12 \\
\hline Leptodora kindtii (Focke, 1844) & 0 & 0 & 0,5 & 0,08 \\
\hline Polyphemus pediculus (Linnaeus, 1761) & 0 & 0,11 & 0 & 0,04 \\
\hline Scapholeberis mucronata (O.F. Müller, 1776) & 0,08 & 0,11 & 0 & 0,08 \\
\hline Ceriodaphnia sp. & 0,08 & 0 & 0 & 0,04 \\
\hline Daphniidae g. sp. Juv. & 0,08 & 0,11 & 0 & 0,08 \\
\hline Итог: Cladocera & $2,24(8)$ & $1,43(8)$ & $2(4)$ & $1,95(13)$ \\
\hline
\end{tabular}


Любин П.А., Зиганшин И.И.

Состав и структура зоопланктона как индикатора экологического состояния водной среды. .

Общая биология

\begin{tabular}{|c|c|c|c|c|}
\hline Таксоны & Участок-1 & Участок-2 & Участок-3 & В целом \\
\hline \multicolumn{5}{|l|}{ Copepoda } \\
\hline Eurytemora lacustris (Poppe, 1887) & 0,23 & 0 & 0,25 & 0,15 \\
\hline Limnocalanus macrurus G.O. Sars, 1863 & 0,08 & 0 & 0 & 0,04 \\
\hline Mesocyclops leuckarti (Claus, 1857) & 0,38 & 0,67 & 0,75 & 0,54 \\
\hline Paracyclops affinis (Sars, 1863) & 0,15 & 0 & 0 & 0,08 \\
\hline Maxillopoda g. sp. & 0,15 & 0 & 0 & 0,08 \\
\hline Nauplius Maxillopoda g. sp. & 1 & 0,78 & 1 & 0,92 \\
\hline Copepodid Maxillopoda g. sp. & 0,46 & 0,78 & 0,75 & 0,62 \\
\hline Итог: Copepoda & $2,45(7)$ & $2,23(3)$ & $2,75(4)$ & $2,43(7)$ \\
\hline Bivalvia & 7 & 3 & 4 & 7 \\
\hline Bivalvia larva & 0,38 & 0,56 & 0,5 & 0,46 \\
\hline Итог: Bivalvia & $0,38(1)$ & $0,56(1)$ & 0,5 & $0,46(1)$ \\
\hline Общий итог: & $11,71(44)$ & 8,97 (34) & $7,75(17)$ & $10,22(61)$ \\
\hline
\end{tabular}

Примечание. Итог - среднее количество видов на станции по участку, в скобках указано общее количество видов.

Биомасса зоопланктона на станциях варьировала от 0,029 до $11,254 \Gamma / \mathrm{M}^{3}$, в среднем составляя $0,679 \pm 0,434 \Gamma / \mathbf{M}^{3}$. Минимальная биомасса зоопланктона была отмечена в районе поселка Рыбная Слобода (ст. 6), максимальное значение ниже по течению от плотины Нижнекамской ГЭС (ст. 22). Средняя биомасса зоопланктеров в Камском отроге Куйбышевского водохранилища составила $0,333 \pm 0,087$ г $/ \mathrm{M}^{3}$. Доминирующей группой по биомассе были коловратки, на их долю приходилось $42 \%$ от общей биомассы $30-$ опланктона, второе место занимали копеподы, на их долю приходилась $1 / 3$ всей биомассы, на третьем месте кладоцеры $-25 \%$, доля личинок двустворок была незначительна. В реофильном участке средняя биомасса зоопланктона на станциях составила $1,448 \pm 1,302 \Gamma / \mathbf{M}^{3}$. На данном участке также ведущее место занимали коловратки - 46\%, но второе место принадлежало кладоцерам, третье - копеподам, их доля составила соответственно $36 \%$ и $17 \%$. На участке Нижнекамского водохранилища средняя биомасса

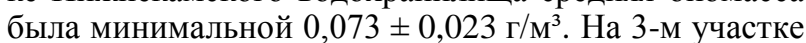
серьезно поменялись доминирование групп: на первом месте были ветвистоусые рачки - 46\%, веслоногие и коловратки имели почти равную долю в общей биомассе по $26 \%$, около $2 \%$ от общей биомассы приходилось на долю личинок двустворчатых моллюсков. В целом по району исследования по биомассе в районе исследования доминировали коловратки $41 \%$. Доля веслоногих рачков в общей биомассе составила $32 \%$, доля ветвистоусых не превышала 27\%, остальная доля, менее 1\%, приходилась на долю личинок двустворчатых моллюсков.

Величина вторичной суточной продукции зоопланктона $\left(\mathrm{P}_{1}\right)$ колебалась в пределах $0,0002-$ $0,524 \Gamma / \mathrm{M}^{3} /$ сутки, при этом среднее значение суточной продукции зоопланктона составило $0,043 \pm$ $\pm 0,020$ г $/ \mathrm{M}^{3} /$ сутки. Минимальная продукция была отмечена около населенного пункта Рыбная Слобода (ст. 6), максимальная у Набережных Челнов (ст. 22). Средняя продукция на станциях была выше в реофильном участке $0,086 \pm 0,059 \Gamma / \mathrm{M}^{3} /$ сутки. В три раза меньше показатели были на станциях Камского отрога Куйбышевского водохранилища $-0,025 \pm 0,009$. Низкие показатели продукции были отмечены для станций Нижнекамского водохранилища $-0,008 \pm 0,001$ г/ $\mathrm{M}^{3} /$ сутки. По продукции в районе исследования доминировали веслоногие рачки 52\%, на долю кладоцер приходилось $38 \%$, доли коловраток и личинок двустворок по продукции составили соответственно 9\% и $1 \%$.

Проведенный кластерный анализ сходства станций по вкладу видов в общую продукцию с исполь- зованием индекса Чекановского [17] позволил выделить группы станций, отличающихся между собой по фаунистическому составу, продукционным показателям и структуре зоопланктонных сообществ (рис. 2). Анализ дендрограммы позволил выделить на исследованной акватории пять комплексов $(I-V)$.

На фаунистический состав и структуру сообществ зоопланктона на станциях в определенной степени влияет, на каком из трех выделенных нами участком нижней Камы проводился отбор проб. Чтобы определить степень значимости географического расположения станций на структуру сообществ, был проведен двухфакторный анализ методом ANOSIM. Анализ влияния факторов проводился по матрице сходства станций.

Анализ показал, что общее значение R статистики для всей модели (выделенных нами сообществ) = 0,798 при уровне значимости $\mathrm{p}=0,1 \%$, что говорит о высокой статистической значимости и в целом не случайности их группировки и отличия выбранной нами модели от нулевой гипотезы (табл. 2). Между тем различия между кластерами II и III менее существенны, чем между остальными: $\mathrm{R}=0,635$ при $\mathrm{p}=2,4 \%$. Анализ влияния такого фактора, как участок реки, на структуру сообщества показал, что различий в фаунистической структуре станций между 1 м и 2-м участком нет: $\mathrm{R}=-0,098$ при $\mathrm{p}=76,2 \%$, более того, имеются внутригрупповые различия. Довольно сильные различия наблюдаются между 1-м и 3-м, 2-м и 3-м. В целом проведенный анализ показал статистически обоснованным выделение нами сообщества (кластерами) по данной модели, а также то, что локальные особенности биотопов в месте отбора проб сильнее влияют на структуру зоопланктона, чем общие условия на участках исследованя.

Распределение выделенных сообществ в районе исследования показано на карте (рис. 3).

Основные качественные и количественные характеристики выделенных нами сообществ приведены в таблице 3.

Как видно из таблицы на станциях, относящихся к I и V типу сообществ, как по продукции, так и по биомассе доминировали кладоцеры, ведущим видом был крупный рачок D. longispina. В сообществе V, которое было представлено одной станцией, расположенной в Нижнекамском водохранилище, биомасса этого рачка достигала рекордной величины 11 г/м³. На станциях, выделившихся во II тип сообществ, преобладали веслоногие рачки M. leuckarti и коловратки B. calyciflorus, также важное значение в сообществе играли личинки веслоногих рачков. В III и IV типе сообществ лидировали крупные коловратки A. priodonta. 


\begin{tabular}{lllllllllll}
\hline & 1 & 1 & 1 & & 1 & 1 & 1 & 1 & 1 & \\
10 & 20 & 30 & 40 & 50 & 60 & 70 & 80 & 90 & $100 \%$
\end{tabular}

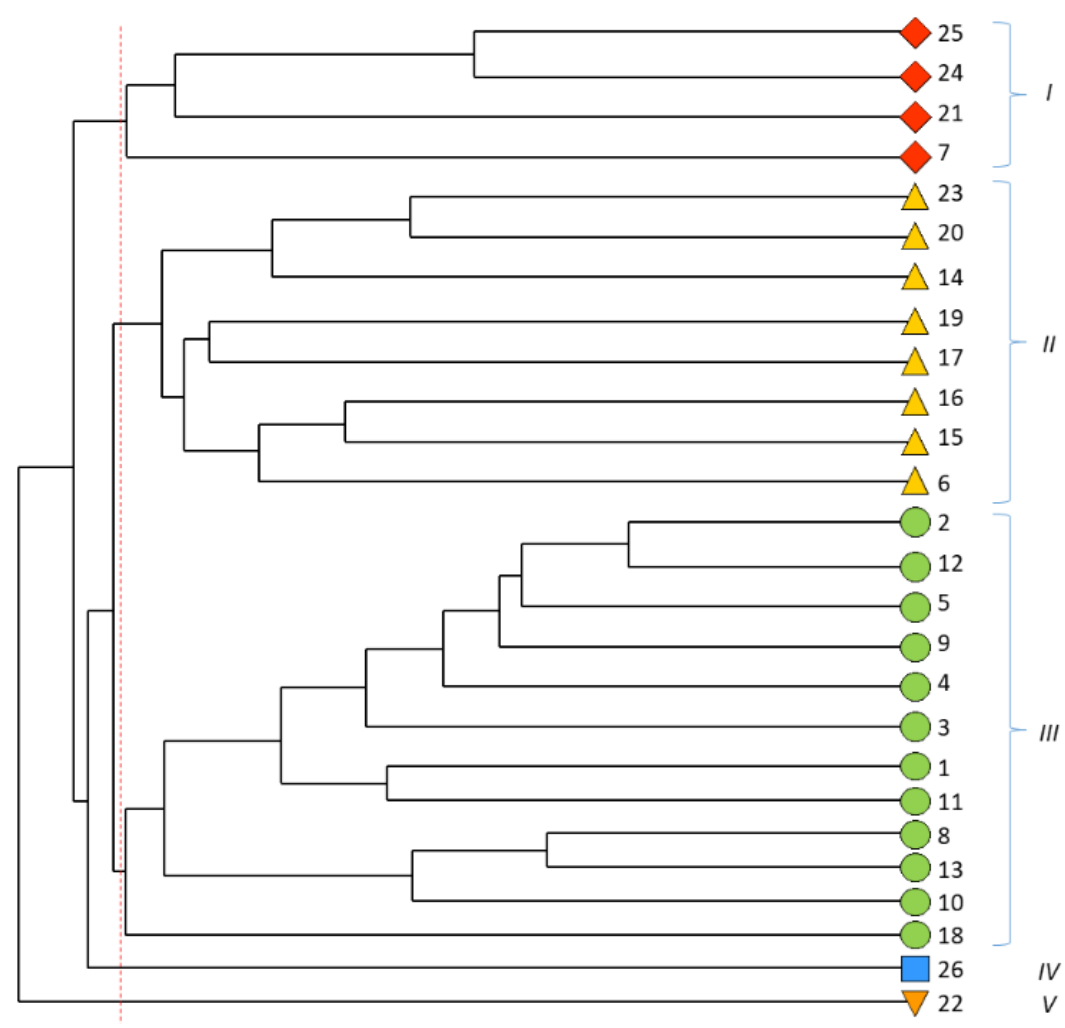

Рисунок 2 - Результаты кластерного анализа сходства станций (по величине вторичной продукции зоопланктеров); I-V- выделенные фаунистические комплексы

Таблица 2 - Результаты двухфакторного ANOSIM анализа выделенных зоопланктонных сообществ по матрице сходства станций

Общий тест различий станций между кластерами (по усредненным данным по участкам)

Общее реальное R: 0,798

Уровень значимости р: $0,1 \%$

Число случайных вариантов: 999

Число случайных вариантов, давших значение, большее или равное реальному R: 0

Попарный тест различий станций между кластерами (по усредненным данным по участкам)

\begin{tabular}{|c|c|c|c|c|}
\hline Кластерные пары & $\begin{array}{c}\mathrm{R} \\
\text { Статистика } \\
\end{array}$ & $\begin{array}{c}\text { Уровень } \\
\text { значимости, \% }\end{array}$ & $\begin{array}{c}\text { Возможное } \\
\text { число подстановок }\end{array}$ & $\begin{array}{c}\text { Произведенное } \\
\text { число подстановок }\end{array}$ \\
\hline I-II & 0,959 & 4,8 & 21 & 21 \\
\hline I-III & 0,878 & 8,3 & 12 & 12 \\
\hline I-IV & 1 & 33,3 & 3 & 3 \\
\hline $\mathrm{I}-\mathrm{V}$ & мало данных & - & - & - \\
\hline II-III & 0,635 & 2,4 & 84 & 84 \\
\hline II-IV & мало данных & - & - & - \\
\hline II-V & 1 & 14,3 & 7 & 7 \\
\hline III-IV & мало данных & - & - & - \\
\hline III-V & мало данных & - & - & - \\
\hline IV-V & мало данных & - & - & - \\
\hline
\end{tabular}

Общий тест различий станций между участками (по усредненным данным по кластерам)

Общее реальное R: 0,413

Уровень значимости р: $6,2 \%$

Число случайных вариантов: 999

Число случайных вариантов, давших значение, большее или равное реальному R: 61

Попарный тест различий станций между участками (по усредненным данным по кластерам)

\begin{tabular}{c|c|c|c|c|}
\hline Кластерные пары & $\begin{array}{c}\mathrm{R} \\
\text { Статистика }\end{array}$ & $\begin{array}{c}\text { Уровень } \\
\text { значимости, \% }\end{array}$ & $\begin{array}{c}\text { Возможное } \\
\text { число подстановок }\end{array}$ & $\begin{array}{c}\text { Произведенное } \\
\text { число подстановок }\end{array}$ \\
\hline Уч. 1 - Уч. 2 & $-0,098$ & 76,2 & 21 & 21 \\
\hline Уч. 1 - Уч. 3 & 1 & 33,3 & 3 & 3 \\
\hline Уч. 2-Уч. 3 & 0,627 & 1,2 & 84 & 84 \\
\hline \hline
\end{tabular}




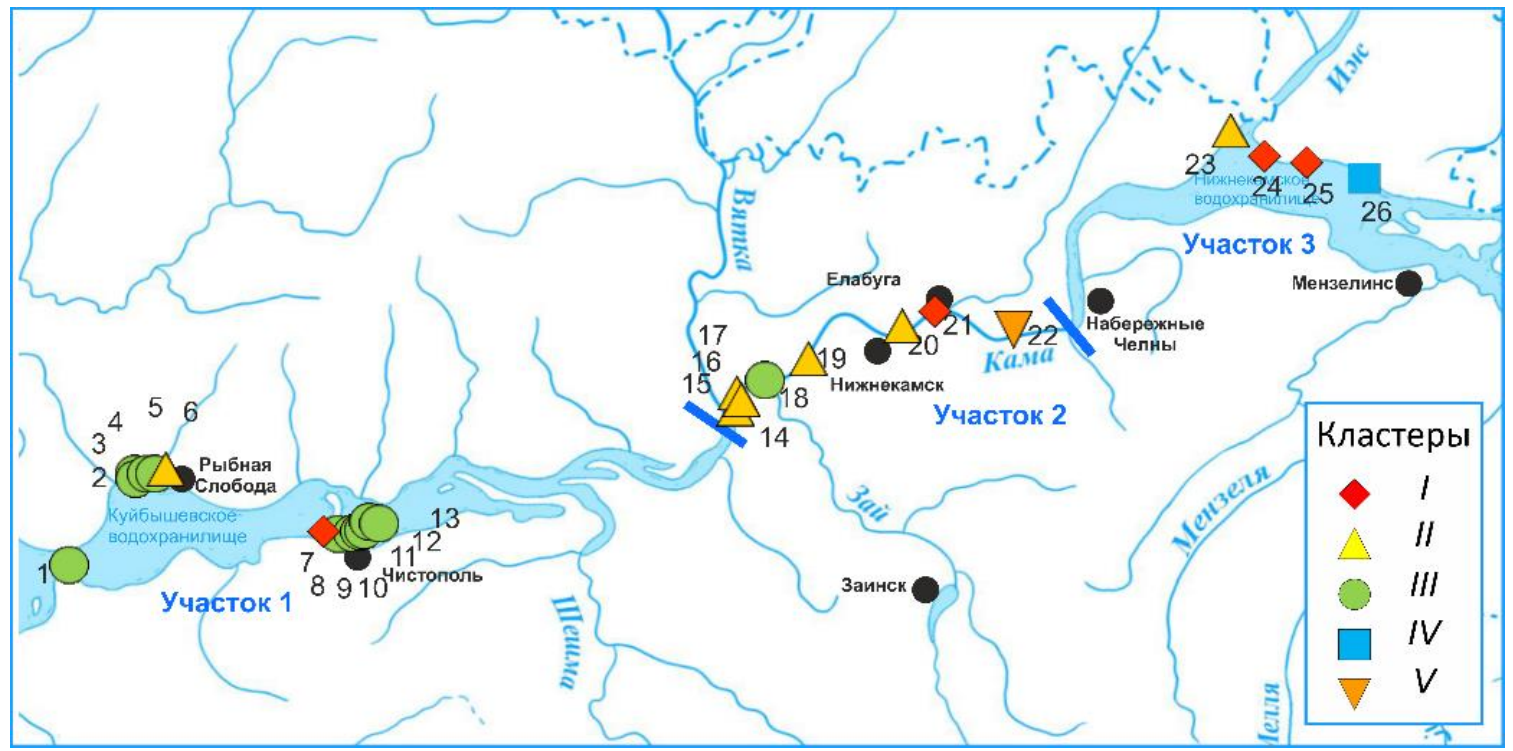

Рисунок 3 - Пространственное распределение основных комплексов зоопланктона в нижнем течении реки Кама по данным 2016 г.; I-V- выделенные фаунистические комплексы

Таблица 3 - Качественные и количественные характеристики зоопланктонных комплексов в нижнем течении реки Кама по данным 2016 г.

\begin{tabular}{|c|c|c|c|c|c|}
\hline $\begin{array}{c}\text { Зоопланктонные } \\
\text { комплексы и } \\
\text { их характеристика }\end{array}$ & $\begin{array}{l}\text { D. longispina }+ \\
\text { D. brachyurum } \\
(I)\end{array}$ & $\begin{array}{c}\text { M. leuckarti }+ \\
\text { B. calyciflorus }+ \\
\text { B. angularis }(I I)\end{array}$ & $\begin{array}{l}\text { A. priodonta }+ \\
\text { B. longirostris } \\
\text { (III) }\end{array}$ & $\begin{array}{l}\text { A. priodonta }+ \\
\text { T. pusilla }(I V)\end{array}$ & $\begin{array}{c}\text { Daphnia } \\
\text { longispina }(V)\end{array}$ \\
\hline №№ станций & $7,21,24,25$ & $6,14-17,19-20,23$ & $1-5,8-13,18$ & 26 & 22 \\
\hline \multirow{2}{*}{$\begin{array}{l}\text { Число видов } \\
\text { в пробе }\end{array}$} & $8,0 \pm 2,2$ & $9,0 \pm 1,0$ & $12,6 \pm 1,3$ & 7,0 & 7,0 \\
\hline & $(3-12)$ & $(5-14)$ & $(6-21)$ & $(7,0)$ & $(7,0)$ \\
\hline Общее число видов & 18 & 33 & 46 & 7 & 7 \\
\hline \multirow{2}{*}{ Биомасса, г/м³ } & $0,255 \pm 0,192$ & $0,149 \pm 0,065$ & $0,346 \pm 0,086$ & $0,036-$ & 11,25 \\
\hline & $(0,054-0,753)$ & $(0,029-0,560)$ & $(0,103-0,950)$ & $(0,036)$ & $(11,25)$ \\
\hline $\begin{array}{l}\text { Доминанты } \\
\text { по биомассе }\end{array}$ & D. longispina & $\begin{array}{l}\text { M. leuckarti }+ \\
\text { P. pediculus }\end{array}$ & $\begin{array}{l}\text { A. priodonta }+ \\
\text { B. longirostris }+ \\
\text { T. stylata }\end{array}$ & $\begin{array}{l}\text { A. priodonta }+ \\
\quad \text { T. pusilla }\end{array}$ & D. longispina \\
\hline \multirow{2}{*}{$\begin{array}{l}\text { Численность, } \\
\text { тыс. экз./ } \mathbf{M}^{3}\end{array}$} & $9,43 \pm 4,43$ & $29,66 \pm 5,17$ & $77,20 \pm 12,17$ & 12,00 & 73,60 \\
\hline & $(0,44-19,22)$ & $(16,21-51,20)$ & $(24,00-134,46)$ & $(12,00)$ & $(73,60)$ \\
\hline $\begin{array}{l}\text { Доминанты } \\
\text { по численности }\end{array}$ & $\begin{array}{l}\text { M. leuckarti }+ \\
\text { D. longispina }\end{array}$ & $\begin{array}{l}\text { B. calyciflorus }+ \\
\text { B. angularis }\end{array}$ & B. longirostris & $\begin{array}{c}\text { Bivalvia larva }+ \\
\text { T. pusilla }+ \\
\text { A. priodonta }+ \\
\text { B. calyciflorus } \\
\end{array}$ & $\begin{array}{l}\text { D. longispina + } \\
\text { M. leuckarti }\end{array}$ \\
\hline \multirow{2}{*}{$\begin{array}{l}\text { Продукция } \mathrm{P}_{1}, \\
\text { Г/M }\end{array}$} & $0,0043 \pm 0,0022$ & $0,0183 \pm 0,0030$ & $0,0430 \pm 0,0100$ & 0,0081 & 0,0237 \\
\hline & $(0,0001-0,0095)$ & $(0,0082-0,0325)$ & $(0,0177-0,1223)$ & $(0,0081)$ & $(0,0237)$ \\
\hline \multirow{2}{*}{$\begin{array}{l}\text { Продукция } \mathrm{P}_{2}, \\
\Gamma / \mathrm{M}^{3} / \text { сутки }\end{array}$} & $0,0115 \pm 0,0067$ & $0,0154 \pm 0,0094$ & $0,0269 \pm 0,0109$ & 0 & 0,5240 \\
\hline & $(0,0029-0,0287)$ & $(0,0002-0,0384)$ & $(0,0018-0,1120)$ & $(0)$ & $(0,5240)$ \\
\hline \multirow{2}{*}{$\begin{array}{l}\text { Индекс Шеннона } \\
\text { (по биомассе) }\end{array}$} & $1,4 \pm 0,4$ & $2,2 \pm 0,1$ & $2,5 \pm 0,1$ & 1,9 & 0,1 \\
\hline & $(0,6-2,2)$ & $(1,6-3,0)$ & $(1,6-3,3)$ & $(1,9)$ & $(0,1)$ \\
\hline \multirow{2}{*}{$\begin{array}{l}\text { Индекс Шеннона } \\
\text { (по численности) }\end{array}$} & $2,4 \pm 0,4$ & $2,5 \pm 0,2$ & $2,5 \pm 0,2$ & 2,6 & 1,8 \\
\hline & $(1,4-3,1)$ & $(1,8-3,2)$ & $(1,2-3,3)$ & $(2,6)$ & $(1,8)$ \\
\hline \multirow{2}{*}{$\begin{array}{l}\text { Индекс Пантле- } \\
\text { Букка-Сладечека }\end{array}$} & $1,83 \pm 0,03$ & $1,96 \pm 0,07$ & $1,75 \pm 0,03$ & 1,92 & 1,76 \\
\hline & $(1,73-1,88)$ & $(1,62-2,25)$ & $(1,56-1,93)$ & $(1,92)$ & $(1,76)$ \\
\hline \multirow{2}{*}{$\begin{array}{l}\text { Индекс } \\
\text { самоочищения }\end{array}$} & $0,99 \pm 0,01$ & $0,88 \pm 0,21$ & $1,07 \pm 0,06$ & 0,83 & 1,00 \\
\hline & $(0,99-1)$ & $(0,35-1,83)$ & $(0,85-1,45)$ & $(0,83)$ & $(1,00)$ \\
\hline \multirow{2}{*}{$\begin{array}{l}\text { Индекс благопо- } \\
\text { лучия сообщества }\end{array}$} & $-0,38 \pm 0,11$ & $-0,09 \pm 0,05$ & $0,01 \pm 0,06$ & $-0,24$ & $-0,61$ \\
\hline & $-0,53--0,11$ & $-0,26-0,17$ & $-0,39-0,33$ & $-0,24$ & $-0,61$ \\
\hline
\end{tabular}

Индекс Шеннона $H^{\prime}(N)$ на станциях колебался от 1,2 до 3,3 бит/особь, сильных различий по участкам не наблюдалось. В среднем по району исследования величина индекса составила $2,5 \pm 0,1$ бит/особь, что соответствует показателям выше среднего уровня.

Сапробиологический анализ уровня органического загрязнения методом Пантле-Букка показал, что в нижнем течении реки Камы вода соответствует умеренно загрязненным водам ( $\beta$-мезосапробная зона), а индекс сапробности колебался от 1,5 до 2,2 . По участкам величина индекса также мало колебалась, в среднем на станциях 1-го участка величина индекса составила $1,7 \pm 0,02$, на 2-м участке - чуть выше $1,9 \pm 0,07$, на 3 -м участке $1,8 \pm 0,04$. В среднем по 
Любин П.А., Зиганшин И.И.

всему району исследования индекс сапробности составил $1,8 \pm 0,03$.

По экологическим критериям вся исследованная акватория характеризуется в целом ослабленным, а в некоторых местах (ст. 6 уч.-1 и ст. 14 уч.-2) - неуравновешенным потенциалом зоопланктонных сообществ к самоочищению вод. Индекс самоочищения изменялся от 0,35 до 1,8 .

Оценка состояния сообществ зоопланктона по индексу благополучия указывает, что сообщества зоопланктеров нижнего течения реки Камы находятся в пороговом состоянии, близком к стрессовому $-0,1 \pm 0,04$. Однако на двух станциях (ст. 7 уч.-1 и ст. 22 уч.-2) индекс достигает значений $-0,5$ и $-0,6$ соответственно, что свидетельствует о тенденции к стабилизации сукцессионных процессов в зоопланктонных сообществах в этих точках.

\section{Обсуждение}

Сравнивая результаты наших исследований с данными Института биологии внутренних вод [9], отметим, что, по данным ИБВВ, в средней Волге и в Камских водохранилищах обитает до 200 видов планктонных беспозвоночных [30]. Нами в нижнем течении реки Камы и в Камском отроге Куйбышевского водохранилища был выявлен 61 таксон, что составляет около $30 \%$ от общего видового списка обитающих в районе исследования видов. По данным В.И. Лазаревой с соавторами [9], в среднем в Куйбышевском и Нижнекамском водохранилищах на станциях встречается по $29 \pm 2$ вида. В нашем материале, из нижнего течения реки Камы, максимальное количество видов на станции не превышало 21 таксон, в среднем таксономическое обилие на стации составило $10 \pm 1$ видов. Полученные нами данные о видовом обилии в три раза ниже приводимых в литературе [9]. Столь сравнительно низкое видовое обилие, возможно, связано с тем, что в наших исследованиях мы ограничивались только сборами зоопланктона из прибрежной полосы реки Камы, тогда как сборы сотрудников ИБВВ проводились путем тотального облова сетью Джеди всего водного столба от дна до поверхности. Однако соотношение таксономических групп в нашем материале было близким к литературным данным: в среднем на станциях около $50 \%$ от видового списка приходилось на долю коловраток, по 25\% на долю ветвистоусых и веслоногих рачков. Показатели обилия зоопланктона в наших сборах были ниже, чем по данным В.И. Лазаревой с соавторами [9]. В Нижнекамском водохранилище средняя численность метазоопланктона, по данным ИБВВ, составляет около 238 тыс. экз./ $/ \mathrm{M}^{3}$, а биомасса

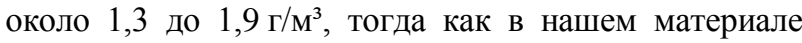
средняя численность составила 50 тыс. экз. $/ \mathrm{M}^{3}$, а биомасса $0,6 r / \mathrm{M}^{3}$. Однако эти показатели хорошо соотносятся с более ранними данными [31] и данными ИБВВ [9] по Куйбышевскому водохранилищу. Биологическое разнообразие зоопланктонных сообществ было чуть ниже значений, показанных для Волго-Камского плеса Куйбышевского водохранилища в 1992 г. [31].

Вторичная продукция зоопланктонных сообществ сотрудниками ИБВВ, к сожалению, не оценивалась, но проведенные нами расчеты вторичной продукции по методу И.Е. Манушина [16] $0,043 \pm 0,020$ г/ $\mathbf{M}^{3} /$ сутки хорошо соотносятся с июльскими данными 1984 г. А.Ф. Тимохиной [31] по Камскому плесу Куйбышевского водохранилища для мирного и хищного зоо-

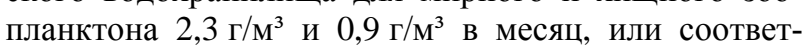

ственно 0,074 г/ $\mathrm{M}^{3} /$ сутки и $0,029 \Gamma / \mathrm{M}^{3} /$ сутки. За вегетативный сезон продукция зоопланктона в районе

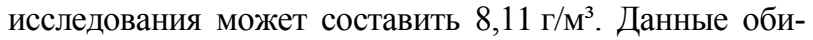
лия также хорошо согласуются с данными 2005 г. [32].

Несмотря на то, что исследуемый район является хозяйственно важным, в литературе крайне мало информации по использованию сообществ зоопланктона для определения качества вод и состояния биоты. По данным Н.А. Дзюбан и С.П. Кузнецовой, индекс сапробности в Куйбышевском водохранилище в 1977 г. составлял 2,0, в 1979 г. - 1,9, весной 1980 г. он составлял от 2,04-2,14 [33; 34]. По нашим данным, в 2016 г. индекс сапробности в районе исследования колебался от 1,5 до 2,2, что говорит о довольно стабильной ситуации в реке Каме на протяжении нескольких десятков лет.

\section{Заключение}

Таким образом, проведенные исследования по прибрежному зоопланктону показали, что ситуация с качеством воды за последние 30-40 лет значимо не изменилась. Вода в нижнем течении реки Камы соответствует умеренно загрязненному классу вод $(\beta$ мезосапробная зона). Таксономическое обилие в прибрежных зоопланктонных сообществах ниже, чем на срединных (стремнинных) участках реки. Показатели обилия (биомасса, численность) и продукции в июле месяце значимо не отличаются от данных предыдущих лет. В прибрежном зоопланктоне выделяются 5 групп сообществ, отличающихся друг от друга по таксономическому составу, количественным характеристикам и по доминированию в них видов. На распределение сообществ сильнее влияют локальные особенности местных биотопов в точке отбора проб, чем общие условия на участках исследования. Характерными видами в районе исследования были коловратки Brachionus calyciflorus, Brachionus angularis, ветвистоусый рачок Bosmina longirostris и веслоногий рачок Mesocyclops leuckarti, встретившиеся более чем на половине станций. Индекс биоразнообразия зоопланктона в прибрежных участках колеблется в довольно широких пределах, но в среднем составляет 2,5 бит/особь. По уровню благополучия прибрежные сообщества зоопланктона находятся на пороговом уровне, близкому к стрессу. Индекс самоочищения прибрежных сообществ низок и характеризуется ослабленным и неуравновешенным потенциалом к восстановлению среды.

\section{Список литературы:}

1. Андроникова И.Н. Структурно-функциональная организация зоопланктона озерных экосистем разных трофических типов. СПб.: Наука, 1996. 189 с.

2. Кортунова Т.А. Зоопланктон Камского водохранилища и его продукция // Комплексные исследования рек и водохранилищ Урала. Пермь: Пермский гос. ун-т, 1983. С. 68-74.

3. Кортунова Т.А., Галанова А.А. Зоопланктон // Биология Воткинского водохранилища. Иркутск: Иркутский гос. ун-т, 1988. С. 50-64.

4. Преснова Е.В., Хулапова А.В. Структура и распределение зоопланктона в центральном районе Воткинского водохранилища // Вестник Пермского унта. Биология. 2015. Вып. 4. С. 366-370.

5. Селеткова Е.Б. Зоопланктон Камского водохранилища // Биоценозы рек и водохранилищ Западного Урала. СПб.: Гос. науч.-исслед. ин-т озерн. речн. рыбного хоз-ва, 2015. С. 136-151. 
6. Куйбышевское водохранилище. Л.: Наука, 1983. $214 \mathrm{c}$.

7. Куйбышевское водохранилище (научно-информационный справочник). Тольятти: Ин-т экологии Волжского бассейна РАН, 2008. 123 с.

8. Поскрякова Н.П. Зоопланктон Камы в августе 1975 г. // Биология внутр. вод. Информ. бюл. 1977. № 36. С. 57-60.

9. Лазарева В.И., Сабитова Р.З., Быкова С.В., Жданова С.М., Соколова Е.А. Распределение летнего зоопланктона в каскаде водохранилищ Волги и Камы // Тр. ИБВВ РАН. 2018. Вып. 83 (86). С. 62-84.

10. Методические рекомендации по сбору и обработке материалов при гидробиологических исследованиях на пресноводных водоемах. Зоопланктон и его продукция / ред. Г.Г. Винберг, Г.М. Лаврентьева. Л.: ГосНИОРХ, 1982. 34 с.

11. Руководство по методам гидробиологического анализа поверхностных вод и донных отложений / под ред. В.А. Абакумова. Л.: Гидрометеоиздат, 1983. $239 \mathrm{c.}$

12. Определитель пресноводных беспозвоночных европейской части СССР (планктон и бентос) / отв. ред. Л.А. Кутикова, Я.И. Старобогатов. Л.: Гидрометеоиздат, 1977. $511 \mathrm{c.}$

13. Определитель зоопланктона и зообентоса пресных вод Европейской России. Т. 1. Зоопланктон / ред. В.Р. Алексеев, С.Я. Цалолихин. М.: Товарищество научных изданий КМК, 2010. 495 с.

14. Błędzki L.A., Rybak J.I. Freshwater crustacean zooplankton of Europe: Cladocera \& Copepoda (Calanoida, Cyclopoida) key to species identification, with notes on ecology, distribution, methods and introduction to data analysis. New York: Springer, 2016. 918 p.

15. Численко Л.Л. Номограммы для определения веса водных организмов по размерам и форме тела (морской мезобентос и планктон). Л.: Наука. 1968. 108 с.

16. Манушин И.Е. Средняя масса особи как показатель скорости оборота вещества в популяциях водных эктотермных животных // Чтения памяти К.М. Дерюгина: мат-лы X науч. семинара. СПб.: ЗАО «КопиСервис», 2008. С. 29-34.

17. Czeckanovski J. Zur differencial Diagnose der Neandertalgruppe Korespbl // Dtch. Ges. Antropol. 1909. Bd. 40. S. 44-47.

18. Андреев В.Л. Классификационные построения в экологии в систематике. М.: Наука, 1980. 142 с.

19. Clarke K.R. Non-parametric multivariate analysis of changes in community structure // Australian Journal of Ecology. 1993. Vol. 18. P. 117-143.

20. Clarke K.R., Warwick R.M. Change in marine communities: an approach to statistical analysis and in- terpretation, 2nd edition. Plymouth Mar. Lab. PRIMERE: Plymouth. 2001. 154 p.

21. Clarke K.R., Gorley R.N. PRIMER v5: User manual / Tutorial. Plymouth Routines In Multivariate Ecological Research. Plymouth Mar. Lab. PRIMER-E: Plymouth. 2001. $91 \mathrm{p}$.

22. Любарский Е.Л. К методике экспресс-квалификации и сравнения описаний фитоценозов // Количественные методы анализа растительности. Уфа: БФАН СССР, 1974. С. 123-125.

23. Shannon C.E. A mathematical theory of communication // Bell System Technical Journal. 1948. Vol. 27, № 3. P. 379-423.

24. Денисенко С.Г. Информационная мера Шеннона и ее применение в оценках биоразнообразия (на примере морского зообентоса) // Морские беспозвоночные Арктики Антарктики и Субантарктики. Сер. Исследования фауны морей. Вып. 56 (64). СПб., 2006. C. 35-46.

25. Pantle F., Buck H. Die biologische Überwachung der Gewasser und die Darstellung der Ergebnisse // Gasund Wasserfach. 1955. Bd 96, N 18. 604 p.

26. Sládeček V. The future of the saprobity system // Hydrobiologia. 1965. Vol. 25. P. 518-537.

27. Sladeček V. System of water quality from the biological point of view // Arch. Hydrobiol., Beihefz., Ergebnisse der Limnol. 1973. Bd. 7. P. 1-218.

28. Горшкова А.Т. Пространственный анализ биологического потенциала устойчивости водных экосистем (на примере поверхностных вод Республики Татарстан): автореф. дис. ... канд. геогр. наук. Ярославль, 2003. 24 с.

29. Горшкова А.Т. Оценка уровня самоочищения озер Кабан по анализу зоопланктонного комплекса // Георесурсы. 2012. № 7 (49). С. 29-32.

30. Litvinov A.S., Mineeva N.M., Papchenkov V.G. et al. Volga River Basin // Rivers of Europe / K. Tockner, U. Uhlinger, C.T. Robinson (eds.). Amsterdam: Elsevier, 2009. P. 23-57.

31. Тимохина А.Ф. Зоопланктон как компонент экосистемы Куйбышевского водохранилища. Тольятти: Ин-т экологии Волжского бассейна, 2000. 193 с.

32. Тимохина А.Ф., Кузнецова С.П. Зоопланктон // Куйбышевское водохранилище (науч.-инф. справочник) / отв. ред. Г.С. Розенберг, Л.А. Выхристюк. Тольятти: ИЭВБ РАН, 2008. С. 71-75.

33. Дзюбан Н.А., Кузнецова С.П. Зоопланктон как показатель загрязнения водохранилищ // Гидробиол. журн., 1978. T. XIV, № 6. С. 42-47.

34. Дзюбан Н.А. Зоопланктон // Куйбышевское водохранилище / отв. ред. А.В. Монаков. Л.: Наука, 1983. С. 119-131.

\title{
ZOOPLANKTON OF THE KAMA RIVER, THE FAUNA COMPOSITION AND STRUCTURE, THE ASSESSMENT OF THE ECOLOGICAL STATE OF THE ENVIRONMENT
}

(C) 2020

\author{
Lyubin Pavel Anatolyevich, candidate of biological sciences, senior researcher of Hydrobiology Laboratory \\ Ziganshin Irek Ilgizarovich, candidate of geographical sciences, associate professor, \\ senior researcher of Biogeochemistry Laboratory \\ Research Institute for Problems of Ecology and Mineral Wealth Use of Tatarstan Academy of Sciences
}

(Kazan, Russian Federation)

Abstract. The paper deals with the study of zooplankton in the lower stream of the Kama river, the largest tributary of the Volga, which has important economic importance for the European part of Russia. The obtained results allowed to establish the summer composition of zooplankton fauna of the studied reservoir, to determine the quantitative characteristics of the communities. 61 taxa belonging to 3 types were identified: Rotifera, Arthropoda (Clado- 
cera, Copepoda groups) and Mollusca (Bivalvia). The average species density in the study area is $10 \pm 1$ taxa per station. The average biomass in the study area was $0,679 \pm 0,434 \mathrm{~g} / \mathrm{m}^{3}$, the average number was $49,50 \pm 8,01$ thousand specimens $/ \mathrm{m}^{3}$. The average daily zooplankton production was $0,043 \pm 0,020 \mathrm{~g} / \mathrm{m}^{3}$. The biocenotic analysis has allowed to allocate five types of communities with the dominance of the major species of rotifers, cladocerans and copepods in the study area. The two-factor analysis showed that the structure of communities is more influenced by the local features of biotopes than the general conditions at the study sites. The wellbeing index indicates that the communities of zooplankters in the lower stream of the Kama river are in a state of near stress. The environmental assessment on the composition and structure of types of indicators is possible to attribute this body of water to moderately polluted water ( $\beta$-mezosaprobic zone).

Keywords: ecological condition; spatial analysis; zooplankton; Kama river; cluster analysis; evaluation of selfcleaning; Nizhnekamsk reservoir; Shannon index; secondary production; biomass; abundance; two-factor ANOSIM analysis; saprobic index; wellbeing index.

$* * *$

УДК 635.925: (470.57-25)

DOI 10.24411/2309-4370-2020-11111

Статья поступила в редакцию 26.01.2020

\title{
ОПЫТ ИЗУЧЕНИЯ РАЗМНОЖЕНИЯ ПРЕДСТАВИТЕЛЕЙ РОДА НYDRАNGЕА L. ЧЕРЕНКАМИ В РАЗЛИЧНЫХ ЭКОЛОГИЧЕСКИХ УСЛОВИЯХ В РЕСПУБЛИКЕ БАШКОРТОСТАН
}

(C) 2020

\author{
Мурзабулатова Фануза Кавиевна, научный сотрудник \\ лаборатории дендрологии, лесной селекции и интродукции древесных растений \\ Полякова Наталья Викторовна, кандидат биологических наук,
}

ведущий научный сотрудник лаборатории дендрологии, лесной селекции и интродукции древесных растений Южно-Уральский ботанический сад-институт Уфимского федерального исследовательского иентра РАН (2. Уфа, Российская Федераиия)

\begin{abstract}
Аннотащия. Приведены результаты изучения размножения видов и сортов гортензии зелеными и одревесневшими черенками на базе коллекции Южно-Уральского ботанического сада-института Уфимского научного центра Российской академии наук. Цель работы - изучение размножения черенками видов и сортов рода Hydrangea в ЮУБСИ УФИЦ РАН и выявление оптимальных экологических условий для наиболее эффективного результата черенкования. Проведены опыты по укоренению зеленых черенков на 5 различных вариантах субстратов (песок, торф, смесь песка и торфа, смесь песка и перлита, смесь торфа и перлита), а также с применением в качестве стимуляторов корнеобразования препаратов корневин и гетероаукин. Кроме того, изучено размножение гортензий одревесневшими черенками после различных методов хранения в зимний период. Установлено, что максимальный процент укоренения получается при использовании в качестве субстрата торфа (укоренение достигает 96,7\%). Максимальная корнеобразовательная способность при размножении зелеными черенками с применением стимуляторов корнеобразования (корневин и гетероауксин) отмечена у H. arborescens $(86,6-93,3 \%)$ и ее сортов $(79,8-96,5 \%)$. У древовидных гортензий высокие результаты получаются при размножении как зелеными, так и одревесневшими черенками. Корнеобразовательная способность одревесневших черенков повышается при хранении их в зимний период под снегом.

Ключевые слова: экологические условия; Hydrangea; укоренение; субстраты; стимуляторы корнеобразования; интродукция; Республика Башкортостан.
\end{abstract}

\section{Введение}

Общеизвестно, что растения размножают двумя способами - семенным и вегетативным. Первым способом обычно размножают виды, вторым - культивары (различные формы и сорта). Преимущества вегетативного размножения состоят в том, что полученный таким образом посадочный материал обладает всеми сортовыми признаками родительских форм, цветение у таких растений наступает раньше, что немаловажно для целей ландшафтного дизайна. Существует несколько способов вегетативного размножения: прививки, отводки, деление куста, черенки $[1 ; 2]$. Особое значение методы вегетативного размножения имеют при получении посадочного материала декоративных растений, в частности декоративных кустарников [3; 4].

Гортензии (род Hydrangea L., семейство Hydrangeaceae Dumort.) в настоящее время являются одними из наиболее популярных декоративных кустарни- ков, ценящихся за обильное и продолжительное цветение, крупные соцветия и декоративную форму кустов [5-8]. Естественный ареал распространения гортензий - Китай, частично - Гималаи, Япония, Ceверная и Южная Америка, единично - Филиппины и о. Ява $[9 ; 10]$. В настоящее время род включает около 200 видов и более 350 сортов [11]. Коллекция рода Hydrangea в Южно-Уральском ботаническом садуинституте Уфимского федерального исследовательского центра РАН (далее - ЮУБСИ УФИЦ РАН) представлена 8 видами и 54 сортами, пополнение сортовой части коллекции производится ежегодно [12]. На базе коллекции проводится многолетнее интродукционное изучение представителей рода, получены результаты по интродукционной устойчивости и перспективности интродукции гортензий в Башкирском Предуралье [13; 14]. Наряду с интродукционными исследованиями, ежегодно в ботаническом саду проводятся опыты по изучению различных способов размножения гортензий. 